$\mathbb{T}$ Periodica Polytechnica

Social and Management Sciences

\author{
23(1), pp. 1-6, 2015 \\ DOI: $10.3311 / P$ Pso. 7965 \\ Creative Commons Attribution (1)
}

RESEARCH ARTICLE

\section{Exchange Rates} and Capital Flows

\author{
Imre Tarafás ${ }^{1 *}$
}

Received 29 August 2014; accepted 11 February 2015

\begin{abstract}
Floating exchange rates were supposed to automatically restore the external balance of an economy, leaving monetary policy free to pursue domestic objectives, without the external constraint. There was also a promise that floating exchange rates would not, in fact, fluctuate much and would be rather stable thanks to speculation. Forty years of experience with floating rates do not support such claims. Floating exchange rates have proved to be volatile, have allowed large and persistent current account imbalances, have not relieved monetary policy form the external constraint and often, made it more difficult for monetary policy to achieve domestic policy objectives. What floating exchange rates made possible was the acrossthe-board liberalization of cross-border capital flows which, growing ever higher relative to real economy transactions, have turned the exchange rate, out of a policy instrument, into a mere by-product of the interplay of speculative forces.
\end{abstract}

\section{Keywords}

Exchange rates, Capital flows, Monetary policy

\footnotetext{
${ }^{1}$ Department of Finance, Faculty of Economic and Social Sciences, Budapest University of Technology and Economics, H-1117 Budapest, Magyar tudósok körútja 2., Hungary

*Corresponding author, e-mail: tarafas@finance.bme.hu
}

\section{Fixed versus Floating Exchange Rates}

The first major step on the road to the liberalisation of the financial system, ever more pronounced until the Great Recession, started in the mid-1970s, when the advanced countries abandoned the system of fixed, but adjustable exchange rates, agreed on at Bretton Woods at the end of World War II. Under the Bretton Woods system, countries sometimes devalued or (very rarely) revalued their currency, but more often, monetary policy was used to correct current account imbalances. More often than not, policymakers felt facing a conflict of objectives: a deteriorating current account forced them to adopt restrictive monetary policies, while at the same time, a sluggish domestic economy and rising unemployment would have required expansionary policies. Dissatisfaction with the system was further exacerbated by its asymmetry. Deficit countries forced to adopt restrictive policies pointed out that current account deficits are international imbalances - and so are current account surpluses. There would be no deficits without surpluses, but under the system of fixed but adjustable exchange rates, the burden of international adjustment falls disproportionately on deficit countries: because of constraints on financing, they are forced far earlier to adjust than surplus countries are, and their painful adjustment relieves surplus countries as well, without any pain or adjustment effort on their part.

The fixed but adjustable exchange rates were accompanied by extensive controls on foreign exchange operations. "The broad objective of Exchange Control (was) to conserve... gold and foreign currency resources and to assist the balance of payments." (Bank of England, 1973, p.6) While trade related payments were generally free from controls, or were, once an import licence was obtained, "covered by Open General Licence" (Bank of England, 1973, p.14) - at least in the advanced countries and from the late 1950s on -, capital account transactions - both inward and outward foreign direct investments, portfolio investments, crossborder lending and borrowing - were subject to controls. Trade related payments were regulated to ensure that they are not used to disguise capital transfers, and the same applied to other current account transactions (e. g., travel). 
The simplest and most frequently used form of capital controls was the requirement to obtain licence from the foreign exchange authority, but there were more elaborate - and possibly less rigid - forms as well. Some countries (Italy, Belgium) used, at times, a dual foreign exchange market, with export-import payments taking place at the official, fixed exchange rate, while capital transfers were separated into another market with floating exchange rate. Facing a deteriorating balance of payments in the 1960s, the United States imposed divers regulations on crossborder capital operations: the Federal Reserve required banks to comply with "voluntary credit restrictions" guidelines, the Treasury imposed an "interest equalization tax" on foreign bonds purchased by US residents, and the Department of Trade imposed regulation on American foreign direct investments in other advanced countries and on the repatriation of profits. Countries with sustained current account surpluses and facing massive capital inflows (West Germany, Switzerland) periodically imposed zero or negative interest rates or a 100 per cent reserve requirement on bank deposits by foreigners.

To avoid conflicts of policy objectives experienced under the system of fixed but adjustable exchange rates, one school of economists had long been advocating the adoption of floating exchange rates (Friedman, 1953). According to their argument, exchange rates, floating freely in response to changing demand for, and supply of, a currency would automatically rebalance the balance of payments, as the exchange rate of the currency of a deficit country (its supply exceeding demand) would depreciate, boosting exports and slowing imports; and vice versa for a surplus country. "The fundamental argument for flexible exchange rates is that they would allow countries autonomy with respect to their use of monetary, fiscal and other policy instruments, consistent with the maintanaince of whatever degree of freedom in international transactions they chose to allow their citizens, by automatically ensuring the preservation of external equilibrium." (Johnson, 1969, p.12) Importantly, there was a promise that floating exchange rates would not, in fact, fluctuate much and would be quite stable thanks to speculators. "A freely flexible exchange rate would tend to remain constant so long as underlying economic conditions... remained constant, random deviations from the equilibrium level would be limited by the activities of private speculators, who would step in to buy foreign exchange when its price fell (the currency depreciated in terms of foreign currencies)". (Johnson, 1969, p.17)

Balance of payments adjustment through monetary policy would have implied extremely painful conflicts of objectives following the oil crisis of 1973. The sharp increase in the world market price of oil (and other energy carriers) required a profound change in relative prices, i. e., a large increase in the price of energy (and of energy intensive products and services) relative to all other prices. Inflation had been accelerating is most advanced countries (the Phillips curve had been shifting up-wards and to the right), and the profound realignment of relative prices would have led to a further acceleration of inflation well into the two-digit territory (if it had taken place via an increase in energy prices even faster than general inflation), or would have resulted in a jump in the unemployment rate (if it had taken place through a strong deceleration of the rate of increase in non-energy prices). Whether policy-makers chose accelerated inflation or rising unemployment, it was difficult for them to stay the course for long. Trying to slow an inacceptable rise in inflation quickly led to a no less inacceptable increase in unemployment. Policies switching back and forth under such constraints made it impossible to stick to a fixed exchange rate.

Speculators proved unable to stabilize floating exchange rates in the period following their general adoption from 1973 onwards, under monetary policies shifting frequently and unpredictably between inflation and unemployment objectives. However, from the early 1980s on, central banks in advanced countries adopted monetary policies consistently aimed at price stability. Such monetary policies should have resulted in more stable exchange rates, moving only in response to "underlying economic conditions", with "random deviations" "limited by the activities of private speculators". This is not what has happened.

\section{The Liberalization of the Capital Account}

The liberalization of the capital account started in the mid1970s, soon after the general adoption of floating exchange rates, under the double argument that capital controls can be circumvented and, in any case, they are no longer needed as floating exchange rates take care of external equilibrium.

The movement started in the United States, continued first in the United Kingdom, took place progressively in continental Western Europe in the 1980s, and spread to most formerly centrally planned economies in the 1990s, and much of the developing world. This has lead to ever-increasing international capital flows. According to triennial surveys by the Bank for International Settlements (BIS) daily turnover of world foreign exchange markets grew as follows (in billions of US dollars):

Table 1 (Source: BIS, 2013a)

\begin{tabular}{cc}
\hline Year & Billions of US dollars \\
\hline 1998 & 1527 \\
2001 & 1239 \\
2004 & 1934 \\
2007 & 3224 \\
2010 & 3971 \\
2013 & 5345 \\
\hline
\end{tabular}

Relative to such amounts, official foreign exchange reserves are negligible: at end-2012, total foreign exchange reserves of all countries amounted to somewhat less than 11 trillion USD (BIS, 2013b, p.22). Projecting those daily turnover data onto 
annual basis, it is clear that foreign exchange market turnover far exceeds, at least 50-fold, the value of world trade (according to Unctadstat, world exports amounted to some 18 trillion USD in 2012). In other words, real economy transactions give rise only to a tiny fraction of foreign exchange market activity. The vast majority of foreign exchange market transactions relate to capital flows. Market demand for, and supply of, individual currencies only marginally depend on the amount of exports and imports to be settled; they depend far more importantly on the motives of movers of capital - investors, speculators, bankers, fund managers, etc. There is no reason to think that those motives generate currency demand and supply resulting in exchange rates that equilibrate trade or current account imbalances. Even if (or when) crossborder capital movements are dominated by currency traders followers of fundamental analysis, indicators of the fundamentals of economies are far from providing unambiguous guidance: they are numerous, often point in contradictory directions, "market attention" shifts from one set of indicators to another, the time horizon over which one or another of the indicators is supposed to be determinant is unknown and variable, etc. It is hardly more than pure coincidence if exchange rate movements resulting from such analysis point in the direction of correcting current account imbalances - except over the very long term. And this even without mentioning the influence of currency traders following other strategies: chartists, followers of news or interpretations of news, rumors, herd behavior, etc.

All this, of course, does not mean that current account imbalances do not get corrected under floating exchange rates, but the least one can say is that, based on an analysis of the data of 170 countries covering the period of 1971-2005, there is "an utter absence of any robust association between the de facto nominal exchange rate regime and the speed of current account adjustment" (Chinn and Wei, 2009, p.17). It has been shown that external disequilibria grew much larger after the abandonment of fixed but adjustable exchange rates and the liberalization of the capital account: in the period 1972-2009 and as a percentage of GDP, current account imbalances were, on average, more than twice those in the period 1944-1971. These much bigger imbalances were possible because international capital flows grew fast from the mid-1980s, and especially from 1995 onwards, reaching 17\% of world GDP in 2007 (Haldane, 2010 and Speller et al., 2011).

\section{Capital flows and the real economy: the case of the huge country with a highly developed financial system}

With floating exchange rates and liberalized crossborder capital movements, the logical chain leading from real economy transactions (current account imbalances resulting from export and import flows) via financial flows (changes in foreign exchange reserves or foreign borrowing) to exchange rate changes may easily reverse: financial (capital) flows move the exchange rate up or down, which, in turn, results in current account deficit or surplus or, in other words, to changes in the domestic production/absorption relationship. One example is developments in the balance of payments of the United States and the evolution of the exchange rate of the dollar in the second half of the 1990s. The dollar kept appreciating along with a growing deficit in the current account of the U.S. This was made possible by a massive capital inflow, pushing the exchange rate of the dollar ever higher, which resulted in a deteriorating trade and current account balance. A deteriorating current account reflects a decline in (the rate of growth of) production or/and an increase in domestic absorption and it is difficult to tell which of these two possible consequences (or what combination) prevailed. An appreciating exchange rate hinders exports and stimulates imports, but, at the same time, the capital inflow may contribute to the expansion of productive capacities, balancing or even exceeding the negative impact on domestic output of the deteriorating trade balance (Higgings and Klitgaard, 1998). In the given period and context, there is some reason to think that the overall impact (of the capital inflow and exchange rate appreciation) on domestic output may have been negative. Much of this period saw the development of the dotcom bubble and there is no doubt that part of the capital inflow went to further inflate the bubble with little, if any, positive impact on domestic output. (Dollar appreciation barely outlasted the collapse of the bubble.)

A short while after the collapse the of the dotcom bubble, a real estate boom started, the immediate antecedent of the financial crisis. There are different views on the causes of the real estate bubble. One school holds the view that the main cause was a too loose monetary policy, keeping the federal funds rate between 2002 and 2006 at a much lower level than would have been justified (Taylor, 2009). The other school stresses, beside other factors, the role of the massive purchase by foreigners of US securities of high credit quality: “... an important part $(55 \%)$ of the high-rated securities issued by American residents between 2003 and 2007 was sold to non-residents" (Bernanke, 2011, p.22), partly to emerging economies with excess savings, and partly to the rest of advanced countries, principally Europeans (here defined as the Eurozone plus the UK). "As it turned out after the outbreak of the financial crisis, many European financial institutions financed their purchases of American assets through short-term dollar liabilities, like Treasury bills and bank deposits, the majority of which attracted American investors" (Bernanke, 2011, p.25) "Given the vigour of the demand for safe American assets, it would have been surprising if there had not been a corresponding increase in the supply of such assets... the wish to respond to the demand for safe assets by international investors was a decisive factor in the process of transforming risky loans into well-rated securities" (Bernanke, 2011, p.26) And “... this may 
help explain why the yield on American assets perceived as safe increased little despite the tightening of monetary policy and the large amount of mortgages issued." (Bernanke, 2011, p.26) In other words, international capital movements, including domestic savings intermediated by foreign financial institutions, were powerful enough to blunt the impact of a substantial tightening of the monetary policy of the most powerful of central banks (the federal funds rate increased from $1 \%$ to $5,25 \%$ between 2004 and 2006), feeding the bubble to inflate till collapse. (For a similar analysis see also Hyun Song Shin, 2011). One would be tempted to conclude that this experience shows that even with floating exchange rates "independent monetary policies are possible if and only if the capital account is managed" (Rey, 2013, p.1)

\section{Emerging markets and international capital flows}

For many years now, there has been a familiar analysis of what went wrong in financial crisis - stricken emerging economies. Fiscal and monetary policies had been loose; the exchange rate had been overvalued; an undeveloped and under regulated banking system had gone on a lending binge, onlending short-term funds borrowed abroad to domestic companies and households, often in foreign currencies. After several years, something ignited the crisis: very often, it was investors realizing that the course was unsustainable and withdrew fast and massively from the country's banks and securities markets. To avoid financial crises, it is recommended to pursue disciplined fiscal and monetary policies, let the exchange rate float freely, promote the institutional development of the banking system, adopt adequate financial regulation, etc. Recently, it has been recommended to develop a domestic savings base large enough to replace foreign funds when they are suddenly withdrawn (IMF, 2013).

Needless to say that economic policies and financial regulations can go badly wrong for a multitude of reasons unrelated to international capital flows. Still, the very least one can say is that the present international monetary and financial system does not facilitate the task of pursuing balanced and sustainable policies. Emerging markets are particularly exposed to massive crossborder capital flows resulting from factors outside their control. Recent research emphasizes the role of global factors in international capital flows. Forbes and Warnock analyse episodes of large capital inflows and outflows in 50 emerging and developed economies over the period 1980-2009 and find that "... waves of capital flows are primarily associated with global factors. Global risk, which incorporates both risk aversion and economic uncertainty, is the only variable that consistently predicts each type of capital inflow episode... domestic factors are generally insignificant in explaining capital flow waves". (Forbes and Warnock, 2012, p.236). What is more, "There is a global financial cycle in capital flows, asset prices and in credit growth... (which) co-moves with... a measure of uncertainty and risk aversion of the markets... The global financial cycle is not aligned with countries' specific macroeconomic conditions... (and) one of the determinants of the global financial cycle is monetary policy in the centre country" (Rey, 2013, p.1).

Faced with massive inflows when global risk is perceived to be low (and especially when advanced country monetary policies are expansive), emerging market governments have several policy options - all with serious drawbacks. One answer to surging capital inflows can be letting the exchange rate appreciate, but currency appreciation does not insulate the domestic economy from undesirable consequences: unless the policy starts from a seriously undervalued exchange rate, currency appreciation will hurt competitiveness, the current account and the domestic economy and makes the currency increasingly vulnerable to sudden reversals of capital flows. The result is hardly better if the central bank cuts domestic interest rates (in order to make its currency less attractive to capital inflows) or intervenes in the foreign exchange market to prevent currency appreciation and leaves the excess liquidity in the economy as the resulting inflation, real exchange rate appreciation and deteriorating current account will, over time, invite a reversal of capital flows. And if (when) there is reversal, it is usually brutal. Analysing the impact on emerging markets of the expected tightening of American monetary policy ("tapering talk in the summer of 2013"), Eichengreen and Gupta conclude that "... emerging markets that allowed the largest appreciation of their real exchange rates and the largest increase in their current account deficit in the prior period... saw the sharpest currency depreciation, reserve losses and stock market declines". It is hardly a consolation that "... measures of policy fundamentals and economic performance (the budget deficit, the public debt, the level of reserves, the rate of GDP growth) do not indicate that better fundamentals provided better insulation" (Eichengreen and Gupta, 2013, p.15).

Protecting the economy from an undesirable amount of capital inflow would, theoretically, only be possible through one of two ways. One is sterilized intervention. Intervention in the foreign exchange market could prevent exchange rate appreciation and sterilization could prevent excess liquidity created by intervention from leading to higher inflation, real exchange rate appreciation and current account deterioration. Massive inflows would require massive intervention and sterilization which, even if possible at all in the relatively modest domestic capital markets, would be very costly. Indeed, massive inflows require large low-yielding foreign exchange reserves, as such inflows are mostly portfolio and other financial flows rather than foreign direct investment: “... the Greenspan - Guidotti rule recommends that countries hold foreign exchange reserves equal to 100 percent of their short-term external debt" (Gagnon, 2012, p.5). This recommendation may easily prove over-optimistic. In early 2014, the World Bank warned that "in a 'disorderly 
adjustment scenario' financial inflows could decline 80 per cent for several months" (Financial Times, January 16, 2014, p.24) and then emerging economies with foreign exchange reserve "only" about twice short-term debt plus current account deficit ("Gross External Financing Requirement") would be at risk (Financial Times, January 16, 2014, p.1)

Lastly, the emerging economy facing strong inflows can resort to capital controls. For countries considering the growing participation in the international division of labour as one of the most important drivers of economic development, introducing capital controls is not an easy decision, as "the greater the integration of an emerging market country into global markets, through current account transactions, long-term capital flows, and direct investment, the less efficient will become the control mechanism on short-term capital inflows or outflows" (Lamfalussy, 2000. p.132). Capital controls may distort financial and economic decisions, can be circumvented and, because they can be circumvented, they tend to escalate (loopholes found and exploited by economic agents will have to be closed by additional controls, and so on). Nevertheless, when macroeconomic instruments are no longer available to protect from inflow surges (the exchange rate is not undervalued, no room for further monetary easing or fiscal retrenchment, etc.), when prudential measures in the regulated financial sector are not enough (because much of the inflow takes place via the unregulated, financial and non-financial, sectors) capital controls are inevitable (Ostry et al., 2012, p.3)

If capital controls are inevitable in those circumstances in order to protect the domestic economy from massive destabilizing capital inflows or to preserve domestic policy independence (Rey, 2013), and if they are costly and burdensome, who should bear that burden? The recipient country (ies) alone, or should the burden be partially internalized by source countries (Ostry et al., 2012)?

\section{Burden sharing in international adjustment}

The idea of burden sharing in international adjustment is anything but new (Williamson, 2011). From Keynes' proposal at (or before) the Bretton Woods conference on the post-war international monetary system through various official and academic proposals, attention was given to excessive current account imbalances. This was quite understandable at Bretton Woods and during the decades following World War II, as capital controls were widespread and it could be reasonably assumed that international imbalances originating in capital flows can and will be dealt with through capital controls, without much affecting the real economy. In such a world, current account imbalances can result from developments in the real economy (differences between countries in productivity growth, propensity to save, etc.), or from differences in policies. In both cases, policies should adjust. As deficits cannot emerge without surpluses and vice versa, without adjustment, deficit countries impose surpluses onto surplus countries or, surplus countries impose deficits onto deficit countries

In today's world of free international capital movements, current account deficits can be imposed on a country via capital flows, unless the country accumulates potentially excessive foreign exchange reserves or imposes necessarily costly, distorting and permeable capital controls. Countries get called currency manipulators when they use official financial flows (foreign exchange market interventions) to achieve an exchange rate for their currency that results in a (growing, excessive) current account surplus, imposing current account deficits on other countries (Gagnon, 2012; Bergsten and Gagnon, 2012). Private capital flows can and do achieve the same result. If an efficient international monetary system requires some degree of burden sharing, as it does, in current account adjustment, then it also requires burden sharing between source and recipient countries in managing international capital flows.

Source country contribution to orderly international capital flows could, theoretically, be done through their monetary policy taking into account not just domestic policy objectives, but also international consequences. But generally requiring policy makers to give priority consideration to the international consequences of their activities over domestic policy objectives would be unreasonable and unrealistic. That leaves us with the need for outflow controls in source countries. It is sometimes said that outflow controls are even less efficient (leakier) then inflow controls. This may be true in the case of controls aimed at preventing capital flight (widespread speculation on large currency depreciation or devaluations, heightened political risk, etc.), but it is not clear why outflow controls should be less efficient than inflow controls when outflows are motivated by interest rate differentials, speculation on the appreciation of a currency, etc.

\section{Capital flows and exchange rates}

Given an international monetary and financial system where source and recipient countries share the burden of maintaining orderly international capital flows, would exchange rates be more stable and move more in line with economic fundamentals? One can hope so. If some of the potential capital outflows are retained by source country controls, there is less pressure on recipient countries to suffer excessive currency appreciations or current account deficit (possibly with higher domestic inflation), or both, because capital inflow controls are the costlier and the less effective the higher the pressure.

What would be the interest of source countries in imposing capital controls? First, massive capital outflows from a country may be generated by real or perceived attractions in other countries (interest rate differentials, expected currency appreciations, perceptions of undervalued stock markets, etc.), and the outflows may, at times at least, be contrary to what would be needed by the domestic economy. If, e. g., a country 
pursues quantitative easing with the aim of bringing down long-term domestic interest rates to boost economic activity, the leakage of monetary stimulus via capital outflow weakens the policy (Ostry et al., 2012, p.20). Unless, that is, the (unavowed) aim of quantitative easing is depreciation of the home currency, that is, a currency war. This leads to a second argument in favour of capital outflow control. It is inconsistent to ask current account surplus countries to share the burden of international adjustment (by, e. g., abstaining from foreign exchange market intervention) while refusing the same principle for capital account adjustment.

How much control is needed and how to distribute controls between source and recipient countries? There is no general answer to these questions since the strength of attraction (real or perceived) to move capital out of a country and into another one is variable over time and across countries. Still, there is a need for indicators that help to resolve disputes over which country is responsible for, and should be expected to take action against, undesirable capital in - and outflows. It has been suggested to consider a country currency manipulator if it accumulates reserves beyond specified limits (Bergsten and Gagnon, 2012). Such proposal is, at the very least, ambiguous when not distinguishing between reserve accumulation resulting from foreign exchange market interventions aimed at maintaining an undervalued exchange rate and a current account surplus, and those helping to insulate the domestic economy from the undesirable consequences of capital inflows. In addition to, or rather instead of, reserve accumulation as an indicator, there might be several other approaches; using exchange rate movements may be better than others. Fast appreciating or depreciating exchange rates are much more likely to indicate strong capital in - or outflows than worsening current account imbalances. Countries in such cases should be expected to take action on both sides, sharing the burden of preventing destabilizing capital flows. This would amount to (require) some kind of exchange rate commitment (to a given exchange rate, to a fluctuation band, to a path, etc.). Just as free capital flows must be accompanied by freely floating currencies, preventing destabilizing capital flows requires management of the capital account and that seems to require management of the exchange rate.

\section{References}

Bank for International Settlements (2013a) Triennial Central Bank Survey. Foreign exchange turnover in April 2013: preliminary global results Bank for International Settlements (2013b) 83 ${ }^{\text {rd }}$ Annual Report.

Bank of England (1973). A Guide to United Kingdom Exchange Control.

Bergsten, C. F., Gagnon, J. E. (2012) Currency Manipulation, the US Economy and the Global Economic Order. Peterson Institute for International Economics Policy Brief.

Bernanke, B. S. (2011) Les flux internationaux de capitaux et le repli vers les actifs surs aux États-Unis 2003-2007, Banque de France. Revue de la stabilité financiere. 15.

Chinn, M. D., Wei, S. J. (2009) A Faith-based Initiative Meets the Evidence: Does the Flexible Exchange Rate Regime Really Facilitate Current Account Adjustment?. NBER Discussion Paper

Eichengreen, B. J., Gupta, P. (2013) Tapering Talk: The Impact of Expectations of Reduced Federal Reserve Security Purchases on Emerging Markets. Policy research working paper, Washington, D. C., the World Bank

Forbes, K. J., Warnock, F. E. (2012) Capital Flow Wawes: Surges, stops, flight, and retrenchment. Journal of International Economics. 88 (2) pp. 235-251. DOI: 10.1016/j.jinteco.2012.03.006

Friedman, M. (1953) The Case for Flexible Exchange Rates. In: Essays in Positive Economics. University of Chicago Press.

Gagnon, J. E. (2012) Combating Widespread Currency Manipulation. Peterson Institute for International Economics Policy Brief, June

Haldane (2010) Global Imbalances in retrospect and prospect. speech, Bank of England.

Higgins, M., Klitgaard, T. (1998) Viewing the Current Account Deficit as a Capital Inflow, Federal Reserve Bank of New York. Current Issues in Economics and Finance. 4 (13).

Hyun, S. S. (2011) Global Banking Glut and Loan Risk Premium. Paper presented at the $12^{\text {th }}$ Jacques Polak Annual Research Conference Hosted by the International Monetary Fund, Washington, D. C. - November 10-11, 2011

International Monetary Fund (2013) World Economic Outlook. Chapter 4: The Yin and Yang of Capital Flow Management: Balance Capital Inflows with Capital Outflows.

Johnson, H. G. (1969) The Case for Flexible Exchange Rates. 1969. Federal Reserve Bank of St. Louis Review

Lamfalussy, A. (2000) Financial Crises in Emerging Markets. An Essay on Financial Globalization and Fragility. New Haven - London: Yale University Press.

Ostry, J. D., Ghosh, A. R., Korinek, A. (2012) Multilateral Aspects of Managing the Capital Account. IMF Staff Discussion Note.

Rey, H. (2013) Dilemma not Trilemma: The Global Financial Cycle and Monetary Policy Independence. Available from: www.Kc.frb.org/publications/research/escp/escp-2013.cfm

Speller, W., Thwaites, G., Wright, M. (2011) The future of international capital flows. Bank of England, Financial Stability Paper, no 12., December.

Taylor, J. B. (2009) The Financial Crisis and the Policy Responses: An Empirical Analysis of What Went Wrong. NBER Working Paper Levies.

Williamson J. (2011) Getting Surplus Countries to Adjust. Peterson Institute of International Economics Policy Brief, January. 